\title{
Effects of bedding with recycled sand on lying behaviors, udder hygiene, and preference of lactating Holstein dairy cows
}

\author{
J. A. Kull, H. D. Ingle, R. A. Black, N. L. Eberhart, and P. D. Krawczel ${ }^{1}$ \\ Department of Animal Science, University of Tennessee, Knoxville 37996
}

\begin{abstract}
Effects of bedding with recycled sand and season on lying behaviors, hygiene, and preferences of late-lactation Holstein cows were studied. It was hypothesized that recycled sand will decrease lying time and increase hygiene scores due to increased moisture content and organic matter, and thus a preference for the control sand will be evident. Cows $(\mathrm{n}=64)$ were divided into 4 groups ( $\mathrm{n}=8$ per group) per season. In summer (August to September), cows were balanced by days in milk $(268.1 \pm 11.9 \mathrm{~d})$ and parity $(2.0 \pm 0.2)$. In winter (January to February), mean DIM was $265.5 \pm 34.1 \mathrm{~d}$. Cows were assigned to 1 of 2 treatments using a crossover design with each treatment lasting $7 \mathrm{~d}$ (no-choice phase): bedding with recycled sand (RS; $\mathrm{n}=32$ ) or control (CO; clean sand; $\mathrm{n}=32)$. Stocking density was maintained at $100 \%$. The choice phase allowed cows to have access to either treatment with stocking density at $50 \%$. Accelerometers recorded daily lying time, number of lying bouts per day, lying bout duration ( $\mathrm{min} /$ bout), and total steps per day. Teat swabs, milk, sand samples, and udder hygiene scores were collected on d 0, 3, and 7 of each experimental week. Samples were cultured for streptococci, staphylococci, and gram-negative bacteria. Video data were used to assess bedding preferences. All data were analyzed using the MIXED and GLIMMIX procedures of SAS 9.4 (SAS Institute Inc., Cary, NC). Lying time was not affected by treatment, but cows did take more steps during winter. Bacterial counts were elevated for cows on recycled sand. A preference was observed for clean sand during the summer, but no preference was observed for sand during the winter. Regardless of bedding, the most commonly observed behavior was lying in the stalls, which suggested either bedding might be suitable. Caution should be used with this interpretation of preference, as sand was recycled
\end{abstract}

Received November 14, 2016.

Accepted May 5, 2017.

${ }^{1}$ Corresponding author: krawczel@utk.edu only once. This limited reclamation was still sufficient to potentially alter the composition of sand, driving the observed preference. If these changes in composition continue, then the strength of the preference may also change. However, considering all variables within the current study, recycled sand is a viable bedding source to use for dairy cows.

Key words: dairy cows, bedding, behavior, hygiene, preference

\section{INTRODUCTION}

The interaction between a cow and her environment is critical for overall welfare and production. There is a very wide range of approaches for cow housing. One way to determine the suitability of a cow's environment is by evaluating her ability to achieve the recommended 12 to $13 \mathrm{~h} / \mathrm{d}$ of lying (Jensen et al., 2005). Because cows spend a large portion of their day lying, the bedding surface is one of the primary, direct interactions she has with her environment. Although many different types of bedding are used within dairy farms, inorganic bedding such as sand can have less bacterial growth than organic bedding (Hogan et al., 1999a) and can increase lying time.

The bedding the producer chooses can affect the lying behavior of cows. Farms where sand was used for bedding had $50 \%$ of cows lying down at any given time compared with farms that used straw, sawdust, or composted manure, where only $40 \%$ of cows were observed lying down (Lombard et al., 2010). Lying bout durations have also been reported to be greater on sand-bedded stalls $(92.0 \pm 12.9 \mathrm{~min})$ than with mattress $(47.9 \pm 7.4 \mathrm{~min})$ or box compost stalls (46.1 \pm 18.5 min; van Gastelen et al., 2011). This suggests that a greater comfort level could be associated with sand bedding.

Dry matter of bedding can also play a critical role in lying behaviors and cow health. When cows were housed in freestalls bedded with sawdust with a DM of $26.5 \%$, lying time decreased by $5 \mathrm{~h}$ relative to freestalls with a bedding DM of $86.4 \%$ (Fregonesi et al., 2007). When cows were exposed to beddings with a DM of 
$89.8 \pm 3.7,74.2 \pm 6.4,62.2 \pm 6.3,43.9 \pm 4.0$, and 34.7 $\pm 3.8 \%$, lying time was decreased by $1 \mathrm{~h}$ on the wettest bedding relative to the others (Reich et al., 2010). Lying time was modestly affected until DM was reduced to $34 \%$ or below (Reich et al., 2010). This suggests bedding quality plays a role in lying behaviors.

Although bedding plays an important role in lying behaviors, it can potentially pose a threat to cow health. The relative risk of hygiene may vary depending on bedding because different bedding sources have different bacterial loads. Bacterial counts on teat ends were relatively low with cows housed on sand compared with cows housed on sawdust. However, more streptococci were found on teat ends when cows were housed on sand bedding (Zdanowicz et al., 2004), but clean sand was found to have the lowest growth of Klebsiella pneumoniae (Godden et al., 2008). These differences in bacterial loads are important because they give an indication of growth in sand. Bacterial counts for clean and recycled sand were comparable a week after bedding was added (Kristula et al., 2005), and Harner et al. (2009) reported that bacteria in recycled sand peaked at $72 \mathrm{~h}$. Justice-Allen et al. (2010) found that recycled sand bedding is a source for Mycoplasma spp. bacteria, which can cause mastitis; however, when recycled sand was cleaned with a common disinfectant, Mycoplasma spp. could no longer be isolated.

Cow health is critical when assessing a bedding source; however, when taking into account cow comfort, preference should also be considered. Although both straw and sand were deemed sufficient based on the recommended 12 to $13 \mathrm{~h} / \mathrm{d}$ lying time, when cows were given a choice, a preference was evident for straw over sand (Norring et al., 2008). However, previous exposure with straw likely drove the observed preference. Cows that had previous exposure to sand spent equal amounts of time on sand and sawdust, whereas cows that spent most of their time on sawdust had previous exposure to sawdust (Tucker et al., 2003). Although recycled sand was suggested to be safe as a bedding source for dairy cows, this conclusion was based only on bacterial types and populations (Kristula et al., 2005). Evaluating recycled sand with a cow component to assess cow health has yet to be determined. Furthermore, the current understanding of cow preference has tended to focus on organic versus nonorganic bedding and quality of beddings. Conversely, no research has evaluated the preference of cows strictly between nonorganic beddings. Kristula et al. (2005) concluded there are differences between recycled and clean sand OM, particle size, and DM. This suggests that these factors may help drive a preference for clean or recycled sand and may alter the hygiene of cows. Determining the suitability of a bedding source involves multiple factors such as cow behavior, cow preference, and cow health. The first objective of this study was to determine the effects of using recycled sand as bedding on lying behaviors and hygiene of late-lactation Holstein dairy cows. The second objective was to determine the preference between recycled sand and clean sand among late-lactation Holstein dairy cows.

\section{MATERIALS AND METHODS}

\section{Animal Housing and Management}

This study was conducted at the University of Tennessee's Little River Animal and Environmental Unit (Walland, TN). Sixty-four cows were used with 32 enrolled from August to September 2014 to evaluate summer response and 32 enrolled from January to February 2015 to evaluate winter response. Within each season, cows were assigned to 1 of 4 groups of 8 cows, which were balanced by DIM and parity during the summer $(268.1 \pm 11.9 \mathrm{~d} ; 2.0 \pm 0.2$, respectively). In the winter, cows were only balanced by DIM $(265.5 \pm 6.0 \mathrm{~d})$. All cows were pregnant during the summer; however, in the winter, 16 cows were nonpregnant. The breeding program used timed AI for all nonpregnant cows enrolled on the study. However, if cows were not successfully bred during the first cycle, visual heat was monitored. No evidence was observed of behavioral changes due to heat within the nonpregnant cows used in this study. Cows were milked twice daily between 0700 and $0900 \mathrm{~h}$ and 1730 and $1900 \mathrm{~h}$. Cows were housed in a 4-row free stall barn. Cows were moved into experimental pens $2 \mathrm{~d}$ before the start of the study to allow for a habituation period. Two experimental pens were split into 2 smaller pens, where stalls were blocked off with gates to obtain 1 stall per cow totaling 8 useable stalls per pen. An equal number of freestalls were available on the back and feed bunk alley. The bed length was $2.4 \mathrm{~m}$ with a width of $1.2 \mathrm{~m}$. Neck rail height was $1.2 \mathrm{~m}$ with the brisket board $1.7 \mathrm{~m}$ from the rear curb. Alleyways were flushed with water at 0730 and $1930 \mathrm{~h}$ to rid alleys of manure and other debris.

Feed bunk headlocks were blocked off to provide 8 useable headlocks per experimental pen. Cows were fed fresh TMR 2 times/d (0700 and $1530 \mathrm{~h})$, and feed was pushed up twice daily. The TMR consisted of $60 \%$ corn silage, $25 \%$ pelleted premix grain concentrate, $12 \%$ small grain silage, and 3\% dry hay. Water was available for ad libitum consumption from a ball trough (Ritchie Industries Inc., Conrad, IA). All procedures described were approved by the University of Tennessee Institutional Animal Care and Use Committee. 


\section{Treatments}

Stalls were bedded with either control (clean, unused sand) or recycled sand (reclaimed from the dairy's flushing system). Recycled sand was collected from the gravity slope of the flushing system and stored in an uncovered area. Control sand was stored under a covering. Bedding was manually added daily to maintain level with the rear curb to avoid the decrease in lying time that occurs with bedding depth below the curb (Drissler et al., 2005). Stalls were raked twice daily during each milking to remove any debris and keep sand level with the rear curb. A crossover design was used that allowed for each cow to be their own control.

\section{No-Choice Phase}

The no-choice phase consisted of a 7-d treatment (control or recycled sand) where stocking density was kept at $100 \%$, where one stall was available per cow ( $\mathrm{n}=8$ per experimental pen). Cows were exposed to treatments using a crossover design that was replicated. Two groups started on control and finished on the recycled sand, whereas the other 2 groups started on recycled sand and finished on control. Due to the volume of sand required to impose treatments, cows rotated pens rather than moving treatments among pens. All experimental pens were adjacent, which was expected to maintain a consistent microclimate. For consistency, all cows experienced the no-choice phase before experiencing the choice phase.

Lying Behaviors. IceTag data loggers (IceRobotics Ltd., Edinburgh, Scotland) were attached to the rear fetlock while cows were in the milking parlor $2 \mathrm{~d}$ before start of the experiment to allow for habituation (MacKay et al., 2012). Data loggers collected daily lying times $(\mathrm{h} / \mathrm{d})$, lying bout frequency (number/d), lying bout length ( $\mathrm{min} /$ bout), and total steps (number/d). Each measurement was used to calculate a daily mean for each variable.

Health/Biological. Rectal temperatures were collected to obtain core body temperature on d 0,3 , and 7 of each experimental week while cows were in headlocks or freestalls. Temperatures were collected with a calibrated thermometer (GLA M500HPDT Thermometer and GLA M207R Probe, GLA Agricultural Electronics, San Luis Obispo, CA).

Udder Hygiene. Teat end samples were collected on d 0,3 , and 7 of each experimental week. To assess bacterial loads on teat ends, a sterile cotton swab in $4.5 \mathrm{~mL}$ of PBS was run across the back left teat before teats were prepared for milking on $\mathrm{d} 0,3$, and 7 for wk 1 and 2. Samples were placed on ice until later analysis, and teat swabs were plated within $12 \mathrm{~h}$ of collection of sample. Teat swab samples were prepped by placing $100 \mu \mathrm{g}$ of original sample into $4.5 \mathrm{~mL}$ of PBS for serial dilutions until countable plates were obtained (Hogan et al., 1999b). For each further dilution, 100 $\mu \mathrm{g}$ was placed in $4.5 \mathrm{~mL}$ of PBS until countable plates were achieved. All media were prepared by following standard operating procedures (Forbes et al., 2002), and media were prepared and plated in a consistent manner for milk samples and sand samples. For isolation of gram-negative bacteria, $1 \mathrm{~mL}$ of the appropriate dilution was plated on MacConkey agar (Oxoid Ltd., Basingstoke, UK) that was prepared according to the manufacturer's directions. Baird-Parker agar (Oxoid Ltd.) was used to isolate Staphylococcus spp. by adding $1 \mathrm{~mL}$ of the appropriate dilution to each corresponding plate. For Streptococcus spp., modified Edwards medium (Oxoid Ltd.) was used to isolate bacteria by adding $1 \mathrm{~mL}$ of the appropriate dilution to each plate. Modified Edwards medium was prepared according to the manufacturer's directions with the addition of $0.5 \mathrm{~g}$ of ferric citrate to each liter of agar. All samples were then incubated following the procedures presented by Hogan et al. (1999b). Colony-forming units were manually counted for each agar plate.

After teats were prepared for milking, an aseptic milk composite sample was collected from each quarter on $\mathrm{d}$ 0,3 , and 7 of each experimental week. An alcohol swab was run across each teat end to ensure it was clean before collection of the milk sample, and then each teat was stripped to obtain a composite milk sample. Samples were frozen at $-20^{\circ} \mathrm{C}$ until later analysis (Schukken et al., 1989). Once thawed to room temperature, composite milk samples were prepared using methods proposed by Hogan et al. (1999b). Samples were plated as stated prior in teat-swab analysis, and colony-forming units were manually counted for each agar.

At the beginning of the study and between treatments, udders were cleaned with a brush. Udders were scored for hygiene on d 0,3 , and 7 of each week in the experimental pen. Each cow was visually scored from the rear on a scale of 0 to 3 . A score of 0 indicated splashes of manure covered $<50 \%$ of the area, a score of 1 indicated fresh splashes of manure covered $>50 \%$ of the area, a score of 2 indicated dried and fresh manure covered $>50 \%$ of the area, and a score of 3 indicated the entire area was covered with dried caked manure (Cook, 2002).

Evaluation of Sand Bedding. A representative sample of sand was collected from each stall on d 0,3 , 7,10 , and 14. Cows switched treatments on $\mathrm{d} 7$, but bedding remained the same during the second week and samples were still taken to evaluate bacterial count over time. Each sample of sand was thoroughly mixed before a 25 -g sample was placed in a $120-\mathrm{mL}$ wide-mouth Bio- 
Tite specimen container (Fisher Scientific, Pittsburgh, PA). Samples were placed on ice until later analysis. Sand was plated within $12 \mathrm{~h}$ of collection of the sample. For preparation of plating, the bedding samples procedures from Gooch et al. (2006) were used. Samples were further plated as stated prior for teat-swab analysis, and colony-forming units were manually counted for each agar plate.

Dry matter samples were collected from each pen on d 0,3 , and 7 of each experimental week. A metal scoop was assigned to each treatment and was used to obtain a small amount of bedding from the back third of each stall, in each pen per treatment. Samples were put in a plastic bag (Ziploc, Ziploc Storage Gallon Bags, Racine, WI) in a cold room $\left(4^{\circ} \mathrm{C}\right)$ until ready for analysis. Samples were thoroughly mixed by agitating the bag for at least $1 \mathrm{~min}$ before $25 \mathrm{~g}$ was removed from bag. Samples were oven-dried at $55^{\circ} \mathrm{C}$ for $48 \mathrm{~h}$ and weighed.

HOBO 4-channel analog data loggers (UX120-006M, Onset Computer Corporation, Bourne, MA) were placed in each experimental pen to collect sand temperatures of clean and recycled sand at 15-min intervals. Temperature probes were placed under the railings of stalls to ensure that the temperature collected was that of the sand and not the cow.

\section{Choice Phase}

To determine preference between treatments, all the cows that experienced the no-choice phase $(\mathrm{n}=64)$ were subsequently enrolled into the choice phase and were given the option between clean and recycled sand for 1 wk. Each pen had a total of 16 stalls available with 8 cows per pen to allow each cow to have a stall with each treatment at 50\% stocking density. Bedding treatments were placed in an alternating manner to ensure that each treatment was spread evenly throughout the pen. All cows had previous experience with both treatments during the no-choice phase of the study. Due to lack of pen space, 2 groups were moved to another pen where they maintained grouping away from the herd for a week, whereas the other 2 groups participated in the experiment. A week later, the earlier nonparticipating cows were moved back to the experimental pen.

To determine preference of bedding, video data were analyzed using 10-min scan samples to observe activity of cows within a pen (Fregonesi et al., 2007). Location of stall was recorded to assess whether cows located in the front or back alley had a stall preference. Activity within the stall included lying (any recumbent position), perching (front 2 hooves in stall), and standing (all hooves in stall). Behavior was recorded for a continuous $24 \mathrm{~h}$ each week using an EZ Bullet VF Platinum Weatherproof IR camera (EZWatch, Louisville, KY) positioned above each experimental pen that included 2 of the smaller pens. The camera was mounted above each pen and Turbo View 16 Channel Platinum HD DVR (EZWatch) was used to record data. During the summer, due to technical difficulties, $3 \mathrm{~d}$ of video for each week that provided 24-h periods of uninterrupted data were chosen, and lights were left on each night. In the winter, the last $3 \mathrm{~d}$ of each week were collected and infrared lights were used for nighttime analysis.

\section{Statistical Analysis}

Data were analyzed using a crossover design. Fixed effects were treatment and sample day for lying behaviors, bacterial counts, and hygiene. The random effects were cow within treatment and sequence of events. The MIXED procedure of SAS 9.4 (SAS Institute Inc., Cary, NC) was used for analysis. A log transformation was used to normalize skewed data. Mean separation was configured by the GLIMMIX procedure to assess means. Least squares means are reported for continuous data, and the frequency procedure was used for presence/absence percentages for variables with excessive zeros. A mixed model was used for video analysis with cow $(\mathrm{n}=8)$ as the observational unit during the choice phase. Fixed effects for video analysis were location within pen, treatment, and activity. Random effects included pen within location, activity, and treatment. A Poisson distribution was used to assess frequency of activities within a given time.

\section{RESULTS}

Data presented for teat end and bedding bacteria are only representative of winter due to the loss of summer samples. Due to destruction of probes, sand temperatures were not able to be collected.

\section{No-Choice Phase}

Summer Data. Treatment had no effects on lying behaviors (Table 1$)$ or sequences of events $(P>0.05)$. When analyzing body temperatures, temperatures were the same for cows on control and recycled sand $(P$ $=0.17)$ with some daily variation $\left(38.4\right.$ to $38.9^{\circ} \mathrm{C} \pm$ $0.13 ; P<0.001)$. Temperatures did not differ for cows that started on control sand ( 38.5 to $38.4 \pm 0.09$ ), but temperatures did increase from 38.5 to $38.7 \pm 0.09$ for cows that started on recycled sand $(P<0.001)$. No differences were observed in composite milk samples between control and recycled sand for bacterial counts on MacConkey agar $(P>0.05$; Figure 1), Baird-Parker $(0.46 \pm 0.1$ vs. $0.51 \pm 0.1 \mathrm{cfu} / \mathrm{mL} ; P>0.05)$, or modified Edwards $(0.10 \pm 0.04$ vs. $0.09 \pm 0.04 \mathrm{cfu} / \mathrm{mL} ; P$ 
Table 1. Mean and SE of lying time, number of lying bouts, lying bout length, and total steps taken for cows while on control and recycled sand bedding during the no-choice phase in the summer and winter session ${ }^{1}$

\begin{tabular}{|c|c|c|c|c|}
\hline \multirow[b]{2}{*}{ Variable } & \multicolumn{2}{|c|}{ Treatment } & \multirow[b]{2}{*}{$\mathrm{SE}$} & \multirow[b]{2}{*}{$P$-value } \\
\hline & Control & Recycled & & \\
\hline \multicolumn{5}{|l|}{$\overline{\text { Summer }}$} \\
\hline Lying time $(\mathrm{h} / \mathrm{d})$ & 11.8 & 11.5 & 0.34 & 0.28 \\
\hline Number of lying bouts (no./d) & 10.8 & 11.0 & 0.42 & 0.46 \\
\hline Lying bout length ( $\mathrm{min} / \mathrm{bout}$ ) & 69.2 & 66.0 & 3.0 & 0.15 \\
\hline Total steps (no./d) & $1,493.4$ & $1,549.4$ & 138.3 & 0.78 \\
\hline \multicolumn{5}{|l|}{ Winter } \\
\hline Lying time $(\mathrm{h} / \mathrm{d})$ & 11.9 & 11.9 & 0.40 & 0.40 \\
\hline Number of lying bouts (no./d) & 8.8 & 8.8 & 0.55 & 0.89 \\
\hline Lying bout length ( $\min$ /bout) & 86.1 & 86.8 & 4.3 & 0.89 \\
\hline Total steps (no./d) & $1,728.6$ & $1,570.6$ & 103.1 & 0.03 \\
\hline
\end{tabular}

${ }^{1}$ Values shown are for each lying behavior within each treatment $(n=4$ groups of 8 cows, each treatment tested within each group). Cows were on each treatment for $1 \mathrm{wk}$, and then a crossover occurred and cows switched treatments the following week for the no-choice phase of the study.

$>0.05)$. Although the majority of cows scored a 0 for cleanliness, $5.2 \%$ of cows scored a $1,2.6 \%$ scored a 2 , and $1.3 \%$ scored a 3 , hygiene scores were still greater for cows on recycled sand compared with cows on control sand (clean: $0.05 \pm 0.03$; recycled: $0.14 \pm 0.03 ; P$ $=0.02)$.

Winter Data. Treatment had no effects on lying behaviors (Table 1$)$ or sequences of events $(P>0.05)$. However, cows on clean sand did have a greater number of steps $(P=0.03$; Table 1$)$. Body temperatures varied daily $(P<0.001)$ but only ranged from 37.3 to 38.3 \pm 0.30 . Temperatures increased from 37.7 to $38.1 \pm$ 0.09 for cows that started on control sand. However, temperatures did not differ for cows that started on recycled sand as temperatures only changed from 38.2 to $38.1^{\circ} \mathrm{C} \pm 0.09(P<0.0001)$. Cows had increased bacterial counts for MacConkey agar while on recycled sand $(248.7 \pm 77.5$ vs. $30.6 \pm 78.3 \mathrm{cfu} / \mathrm{mL} ; P=0.05)$. Cows on recycled sand had more bacterial counts than cows on control for Baird-Parker agar plates $(P=0.05$; Figure 2). Bacterial counts increased throughout both experimental weeks $(P=0.05$, Figure 2$)$. For composite milk samples, no differences were observed for bacterial counts on MacConkey agar, Baird-Parker agar, or modified Edwards medium ( $P>0.05$; Table 2$)$. Hygiene scores did not differ between control and recycled sand $(0.15 \pm 0.04$ vs. $0.10 \pm 0.04 ; P>0.05)$ as less than $12 \%$ of cows scored above zero.

Bacterial counts did not differ between control and recycled sand on MacConkey following culture (316,096.6 $\pm 181,046.6$ vs. $1,455,179.3 \pm 833,464.6 \mathrm{cfu} / \mathrm{mL} ; P$ $>0.05)$ or Baird-Parker $(1,412,765.1 \pm 863,455.4$ vs. $6,339,798.9 \pm 3,874,765.7 \mathrm{cfu} / \mathrm{mL}, P>0.05)$. Bacterial counts steadily increased throughout the experiment, but peaked on d $7(P=0.04$; Figure 3$)$. Bacterial counts did not differ between control and recycled sand on modified Edwards $(5,172,000 \pm 3,460,527$ vs. $5,950,000$ $\pm 3,460,527 \mathrm{cfu} / \mathrm{mL} ; P>0.05)$. Although bacterial counts did not differ within bedding, a treatment effect was observed where DM was lower for recycled sand samples $(P=0.02$; Table 3$)$.

\section{Choice Phase}

Summer Data. Cows preferred to occupy a control stall compared with a recycled stall $(P=0.03$; Figure $4)$. When cows were in a control stall, they spent the majority of their time lying, compared with perching or standing $(P<0.001$; Figure 5$)$. No preference was evident for perching $(P=0.61)$ or standing $(P=0.88)$ on either surface. Cows preferred lying in either stall compared with perching or standing in a stall $(P \leq$ $0.01)$.

Winter Data. No preference was evident between control and recycled sand $(P=0.69)$. Cows spent the majority of their time lying down in either stall $(P<$ 0.0001 ). Cows spent $27.2 \pm 0.01 \%$ of their time in a recycled sand stall and $25.9 \pm 0.01 \%$ of their time in a clean sand stall $(P=0.46)$. Furthermore, no preference was observed for perching $(P=0.79)$ or standing $(P=$ 0.89 ) on either sand treatment. Cows preferred to be lying in either stall compared with perching or standing in a stall $(P \leq 0.01)$.

\section{DISCUSSION}

Evaluating recycled sand with a cow component involved for cow health has yet to be determined. Furthermore, studies have failed to evaluate cow preference between inorganic beddings such as sand. Assessing cow health and preference is critical to determine the suitability of a bedding source. Within the current 
study, sand bedding did not decrease lying time or affect cow health in a biologically relevant way, implying either bedding may provide a suitable bedding surface. However, a preference was observed for cows to occupy a control sand stall during the summer session of the choice phase.

\section{No-Choice Phase}

There were no effects of treatment on lying behaviors (lying time, h/d; lying bout, no./d; and bout duration, min/d) during either experimental season. Lying time observed in this study was consistent with the $11.0 \pm$ $2.1 \mathrm{~h} / \mathrm{d}$ mean reported by Cook et al. (2004) and the 9.5 to $12.9 \mathrm{~h} / \mathrm{d}$ range reported by Ito et al. (2009). The means for lying bouts and bout duration in the current study were again consistent with reported values of 7 to
10 bouts/d and 65 to $112 \mathrm{~min} /$ bout by Ito et al. (2009). Similarly, results within the current study were consistent with values reported by Gomez and Cook (2010) who observed a range of 8.2 to 12.2 lying bouts/d when cows were housed on sand. This implies that cows are behaving as predicted from existing data, suggesting the time budget of dairy cows was not shifted by either treatment.

A treatment effect was evident for the number of steps in winter. However, with a difference of only 200 steps, the biological relevance of this is questionable. Cows on a compost bedded pack barn had an average of $1,485 \pm 765$ steps/d, which suggests our results may fall within a typical range of normal activity for lactating dairy cows (Eckelkamp et al., 2014). One explanation for the observed difference was there were more open cows in the winter engaging in estrus behavior.

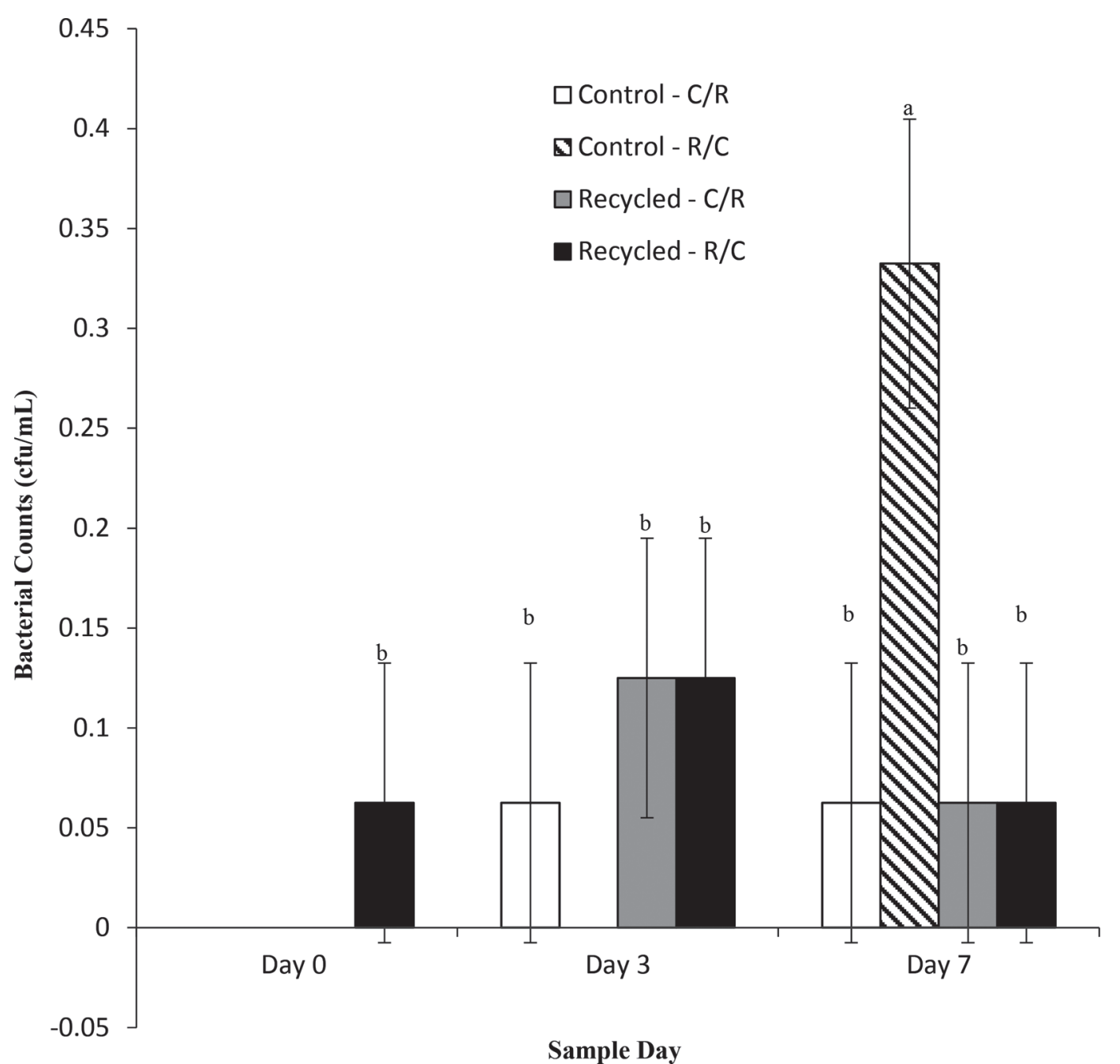

Figure 1. Bacterial counts on modified Edwards medium for winter composite milk samples over time $(\mathrm{n}=32)$. ${ }^{\mathrm{a}, \mathrm{b}}$ Data within sample day with different letter designations differ $(P<0.05)$. $\mathrm{C} / \mathrm{R}=$ experienced clean and then recycled sand; $\mathrm{R} / \mathrm{C}=$ experienced recycled and then clean sand. Error bars indicate SEM. 


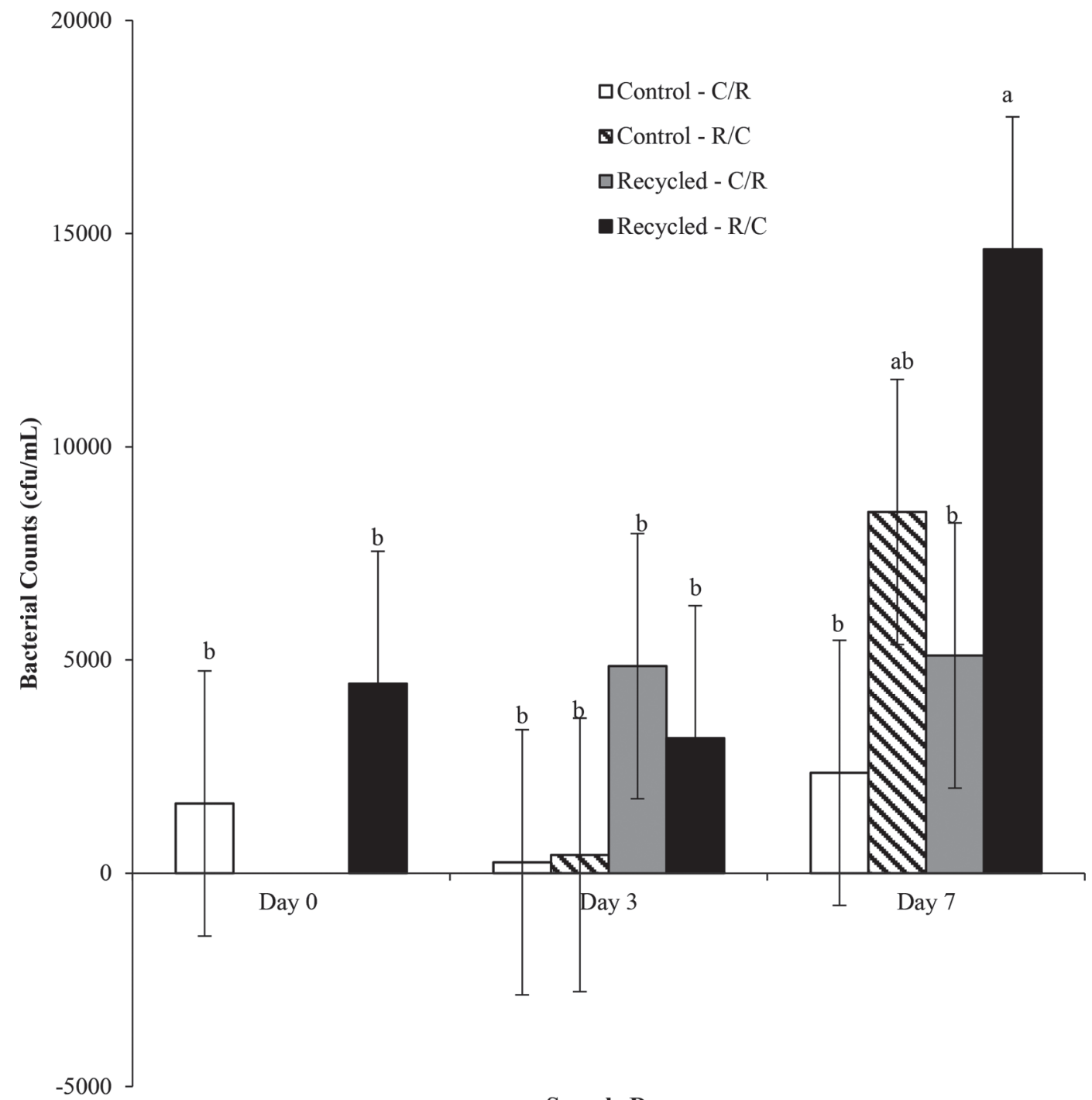

Sample Day

Figure 2. Bacterial counts on Baird-Parker agar for teat swabs during the winter session $(\mathrm{n}=32)$. ${ }^{\mathrm{a}, \mathrm{b}}$ Data within sample day with different letter designations differ $(P<0.01) . \mathrm{C} / \mathrm{R}=$ experienced clean and then recycled sand; $\mathrm{R} / \mathrm{C}=$ experienced recycled and then clean sand. Error bars indicate SEM.

However, Durkin and DeLaval (2010) reported cows in heat having a $100 \%$ deviation from their average steps per hour. For example, he reported cows having an average of $100 \mathrm{steps} / \mathrm{h}$, and then when cows were in heat, their steps increased to 700 steps/h. Furthermore, no

Table 2. Bacterial counts $(\mathrm{cfu} / \mathrm{mL})$ did not differ between treatments for composite milk samples during the winter

\begin{tabular}{|c|c|c|c|c|}
\hline \multirow[b]{2}{*}{ Medium } & \multicolumn{2}{|c|}{ Treatment } & \multirow[b]{2}{*}{$\mathrm{SE}$} & \multirow[b]{2}{*}{$P$-value } \\
\hline & Control & Recycled & & \\
\hline MacConkey & 0.01 & 0.0 & 0.009 & 0.43 \\
\hline Baird-Parker & 0.46 & 0.42 & 0.07 & 0.46 \\
\hline Modified Edwards & 0.17 & 0.21 & 0.06 & 0.52 \\
\hline
\end{tabular}

differences were observed in lying behaviors during the winter, which would suggest no overall change in time budget. Due to the magnitude of increase in steps and the lack of change in lying behaviors, it is unlikely that estrus behavior was the cause of this difference.

Lack of differences within lying behavior were likely due to the differences in DM. Because studies have indicated that DM affects lying behaviors, DM content was determined for both treatments (Fregonesi et al., 2007). A study comparing sawdust DM at 86 and $26 \%$ reported lying time decreased by $5 \mathrm{~h} / \mathrm{d}$ (Fregonesi et al., 2007). Dry matter for the current study only ranged from $88 \%$ at the lowest to $95 \%$ at its highest, whereas the DM in Fregonesi et al. (2007) differed by $60 \%$, suggesting that DM may not have been low enough to 


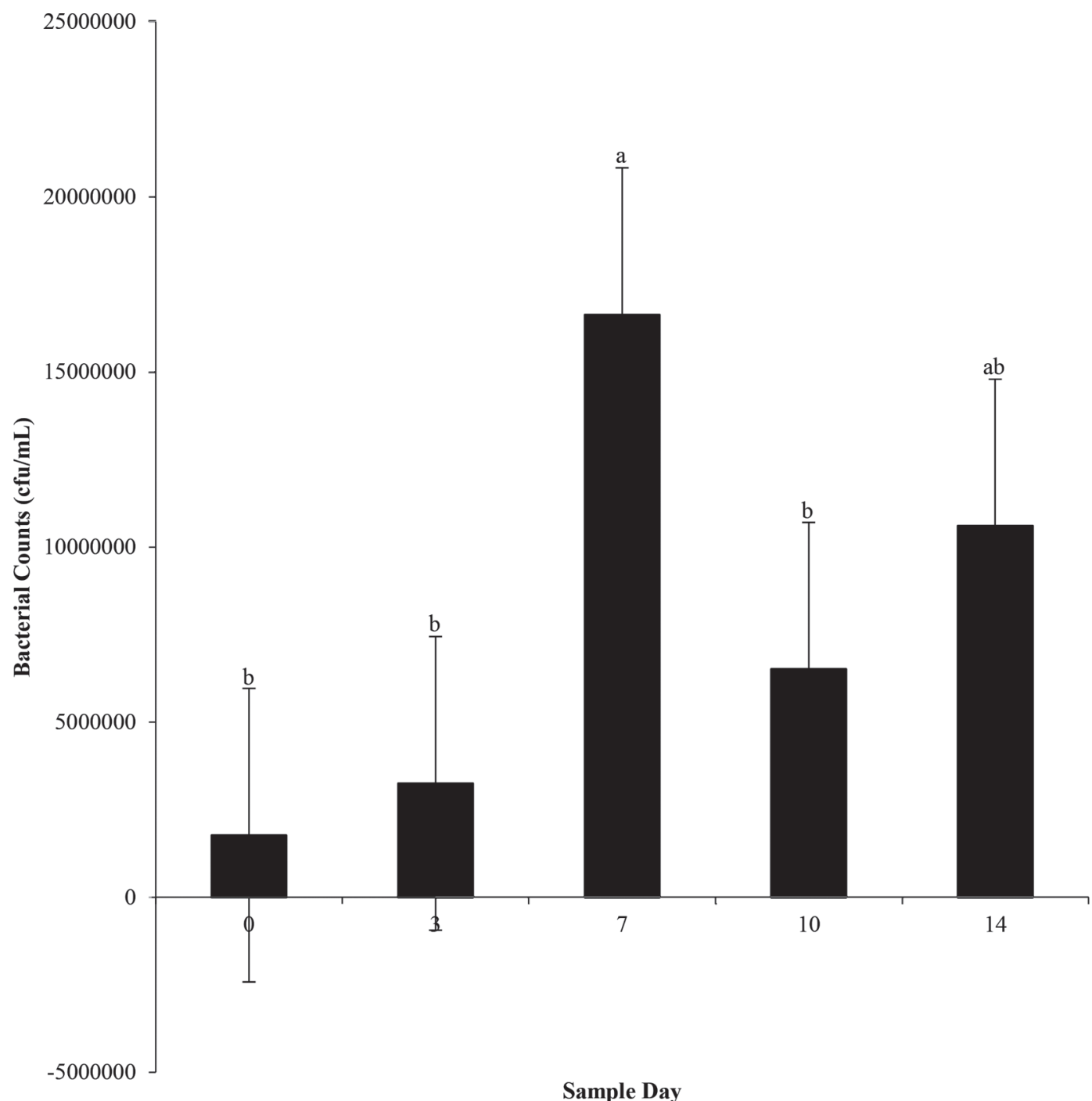

Figure 3. Bacterial counts changed over time for winter sand samples on Baird-Parker agar $(\mathrm{n}=32)$. Samples were collected the same day as all other collections, but treatment did not change within pen for these samples. Samples are representative across sample days. Means and $\mathrm{SE}$ are presented for the sample day that sand samples were collected. ${ }^{\mathrm{a}, \mathrm{b}}$ Data with different letter designations differ $(P<0.05)$.

negatively affect lying behaviors. Differences were observed in DM samples for control and recycled sand for both summer and winter. The reduction in lying time was not present in the current study as DM percent- ages of sand never dropped below $88 \%$. However, results within the current study remained consistent with the results of Kristula et al. (2005), who reported that for sample d 0, the mean DM was $93.6 \pm 3.35 \%$ and

Table 3. Means and least squares SE for bedding DM (\%) for used control (control), new control added (control added), recycled used (recycled), and new recycled sand added (recycled added) for the duration of the summer and winter session

\begin{tabular}{lcccc}
\hline Bedding type & Summer DM $(\%)$ & SE & Winter DM (\%) & SE \\
\hline Control $_{\text {Control added }}{ }^{1}$ & $94.9^{\mathrm{a}}$ & 0.9 & $93.9^{\mathrm{ab}}$ & 1.6 \\
Recycled $^{\text {Recycled added }}{ }^{1}$ & $94.8^{\mathrm{ab}}$ & 1.7 & $94.0^{\mathrm{a}}$ & 1.3 \\
\hline
\end{tabular}

${ }^{{ }^{a-c}}$ Means with different superscripts tended to differ (summer: $P=0.07$; winter: $P<0.05$ ).

${ }^{1}$ Bedding was added daily to maintain level with the rear curb height. 


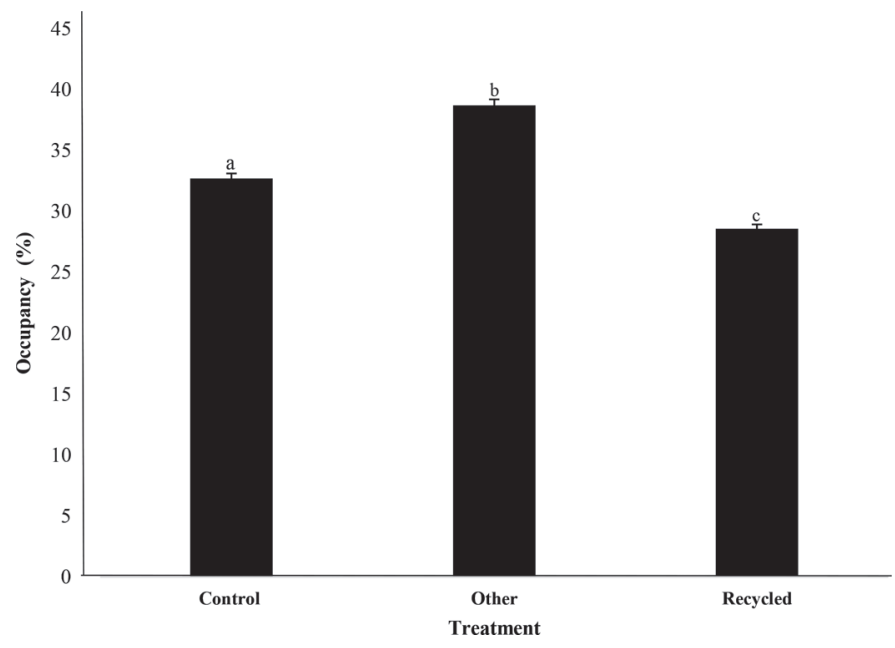

Figure 4. Total time spent in either a control or recycled stall was reported as well as cows engaging in other behaviors $(\mathrm{n}=64)$. "Other" describes cows that were not occupying either stall and were drinking, eating, or standing in the alleyway. ${ }^{\mathrm{a}-\mathrm{c}}$ Values with a different letter differ $(P<0.05)$. Error bars indicate SEM.

$88.5 \pm 5.03 \%$ during the winter session for clean and recycled sand, respectively, as well as $93.99 \pm 4.43 \%$ and $89.51 \pm 5.47 \%$, respectively, during the summer session. However, there may be a threshold to wetness of sand bedding, which may differ from the critical DM of organic bedding, before lying time is decreased.

Because differences are present in DM between recycled and control sand, body temperatures were taken to ensure lying time was not influenced by sand temperature (Kristula et al., 2005). Using conductive cooling dropped cows' body temperatures, suggesting heat-

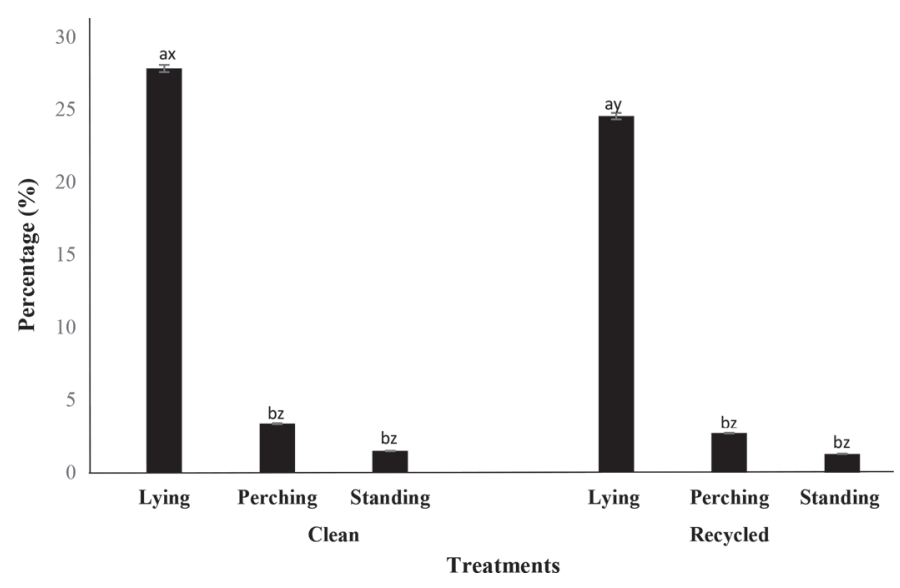

Figure 5. Amount of time cows spent perching (front 2 hooves in stall), standing (all 4 hooves in stall), or lying down (assuming a recumbent position in stall) in either control or recycled sand stalls $(\mathrm{n}=64)$. Means and SE are presented as percentages for each $10-\mathrm{min}$ interval of video data. ${ }^{\mathrm{a}, \mathrm{b}, \mathrm{x}-\mathrm{z}}$ Values with a different letter within a treatment or within a behavior differ $(P \leq 0.01)$. stressed cows may be inclined to lie on the wet or cooler sand (Ortiz et al., 2015). However, lying times were not affected during either experimental season within the current study and no heat stress was evident, suggesting that housing environment was sufficient.

Due to the lack of differences in DM, this potentially explains why the cows within the current study were considered clean. Cows who scored a 1 or 2 had better udder hygiene and were considered clean, unlike cows who scored a 3 or 4 (Schreiner and Ruegg, 2003). This suggests a full numerical point between cows considered clean or dirty. Although overall hygiene scores were greater for cows on recycled sand during the winter, both seasons had scores below those that Schreiner and Ruegg (2003) considered to indicate at-risk cows, suggesting the scores may not be biologically relevant. Furthermore, because the cows within the current study were classified as clean, they had a lower risk for subclinical mastitis as the mean score for cows in this study was below a 1 for both treatments (Schreiner and Ruegg, 2003). Contradictory results have been found for cows' hygiene when bedding with sand. Cows housed on straw were dirtier than cows housed on sand, as Norring et al. (2008) reported a mean cleanliness score of 6.04 and 4.19 for straw and sand cleanliness, respectively. Hygiene scores ranged from 1 to 10 with a score of 10 being the dirtiest (Norring et al. (2008). Zdanowicz et al. (2004) reported that when cows were housed on sawdust, they had cleaner udders than cows housed on sand. However, udder cleanliness did not change on either bedding throughout the study. Although udder hygiene scores for this study indicated the cows were clean, greater bacteria counts were greater for recycled sand, indicating that even with the increased bacterial load, it was still under what is necessary to score a cow above a 0 or 1 based on hygiene.

Teat end bacterial counts for gram-negative bacteria and Staphylococcus spp. were greater for cows on recycled sand compared with control sand. Gramnegative bacteria are more abundant in $\mathrm{OM}$, such as manure, water, and soil (Hogan and Smith, 2003). The evaluation of recycled versus clean sand by Kristula et al. (2005) indicates that there is more OM in recycled sand, implying this could be the reason Staphylococcus spp. was increased for cows on recycled sand. Results from the current study for gram-negative bacteria on teat ends were much lower than existing literature on sand and sawdust. In the current study, gram-negative bacteria was consistent for recycled sand compared with Klebsiella spp. in sand, but coliform bacteria was much greater in sand reported by Zdanowicz et al. (2004). The consistency between these studies may have been the DM for sand within each study. The current study mean DM was $91.7 \%$, whereas Zdanowicz 
et al. (2004) reported DM for sand at 94.7\%. As DM was greater, bedding material may not have adhered to teat ends as much as with a lower DM; however, the threshold for sand DM is still unknown. There could also be the likelihood of an increase in coliform bacteria with each additional reclaiming of recycled sand. Even though differences were found with teat end exposure, this did not translate to increased bacteria in the milk. The bacterial loads from these milk samples were below the general expectance of $<1,000$ bacteria/mL (Kurweil and Busse, 1973), indicating bacterial counts were below what is needed to increase bacteria in the milk for both treatments.

Bacterial counts for sand changed over time for Staphylococcus spp., but no differences were established for gram-negative bacteria or Streptococcus spp. The bacterial counts presented in the current study were consistent with those previously reported on recycled sand. Kristula et al. (2005) reported no differences between bacterial loads in either type of sand, but loads did increase over the sample period. However, it was reported that bedding bacteria normally exceeded bacterial counts of $10^{8}$ to $10^{10}$ per gram of bedding (Hogan et al., 1989), indicating that bacterial loads within this study remain consistent with existing literature. This implies that sand did not pose an environmental risk to these cows.

\section{Choice Phase}

Having cows undergo a choice phase is critical to evaluate if cows have a preference for control or recycled sand. A preference was observed for control sand during the summer treatment; however, no preference was observed during the winter treatment. Depending on prior exposure, DM, and bedding depth, cows may have a preference bias (Drissler et al., 2005; Fregonesi et al., 2007; Norring et al., 2008). This suggest that if cows were exposed to a certain bedding before the preference test, they may have a bias and choose the bedding they are most familiar with. However, because the only difference between treatments was management strategies, a preference bias likely did not occur within the current study. Cows preferred sand and mattresses for stall surfaces over concrete and rubber mats (Wagner-Storch et al., 2003), but preferred soft rubber mats over straw and sand (Manninen et al., 2002). For the current study, the biggest differences between treatments are most likely OM, sand particle size, and moisture content based on the findings of Kristula et al. (2005). Recycled sand had larger particles as well as a greater OM content relative to clean sand (Kristula et al., 2005). Particle size and OM were not evaluated because the current studies main objective was to as- sess recycled sand as a safe bedding source and then to determine if cows had a preference. Although particle size and OM were not considered, these factors had the potential to drive the observed preference. However, it is not known how much the OM in the current study may have changed because bedding was added daily.

In conclusion, recycled sand is considered a safe bedding surface for dairy cows. Results indicated that recycled sand was a comfortable bedding material as lying time was not reduced. Because sand was only reused once, this could explain why cows showed little to no preference of bedding as sand composition may not have been altered with only one reclamation. Further reclamation is needed to evaluate sand composition, udder hygiene, and preference because if these factors were allowed to progress, they may continue to drive the preference for control sand and potentially affect cow health. Bacterial loads within bedding could become a concern. Maintenance of recycled sand bedding would be required often. It is unknown what the threshold of bacterial load is in recycled sand and how many times the bedding can be reclaimed and safely used.

\section{ACKNOWLEDGMENTS}

We thank Charlie Young, Mark Lewis, Sierra Lockwood, and the University of Tennessee Little River Animal and Environmental Unit (Walland) staff for their help and support on the farm. We also thank Arnold Saxton (University of Tennessee, Knoxville) for his statistical consulting. Last, this research was partially supported by USDA Hatch (Washington, DC) funds.

\section{REFERENCES}

Cook, N. B. 2002. Hygiene scoring color chart. University of WisconsinMadison. Modified Sep. 18, 2002. Accessed Oct. 16, 2016. https:// www.vetmed.wisc.edu/dms/fapm/fapmtools/4hygiene/hygiene. pdf.

Cook, N. B., T. Bennett, and K. Nordlund. 2004. Effect of free stall surface on daily activity patterns in dairy cows with relevance to lameness prevalence. J. Dairy Sci. 87:2912-2922.

Drissler, M., M. Gaworski, C. Tucker, and D. Weary. 2005. Freestall maintenance: Effects on lying behavior of dairy cattle. J. Dairy Sci. 88:2381-2387.

Durkin, J., and B. W. DeLaval. 2010. Heat detection: Trends and opportunities. Pages 1-10 in Proc. Second North Am. Conf. Precision Dairy Management, Toronto, Canada. Precision Dairy Operators, Elora, Canada.

Eckelkamp, E. A., C. N. Gravatte, C. O. Coombs, and J. M. Bewley. 2014. CASE STUDY: Characterization of lying behavior in dairy cows transitioning from a freestall barn with pasture access to a compost bedded pack barn without pasture access. Prof. Anim. Sci. 30:109-113.

Forbes, B. A., D. Sahm, and A. Weissfeld. 2002. Diagnostic Microbiology. 11th ed. Mosby, St. Louis, MO.

Fregonesi, J., D. Veira, M. Von Keyserlingk, and D. Weary. 2007. Effects of bedding quality on lying behavior of dairy cows. J. Dairy Sci. 90:5468-5472. 
Godden, S., R. Bey, K. Lorch, R. Farnsworth, and P. Rapnicki. 2008. Ability of organic and inorganic bedding materials to promote growth of environmental bacteria. J. Dairy Sci. 91:151-159.

Gomez, A., and N. Cook. 2010. Time budgets of lactating dairy cattle in commercial freestall herds. J. Dairy Sci. 93:5772-5781.

Gooch, C., J. Hogan, N. Glazier, and R. Noble. 2006. Use of post digested separated manure solids as freestall bedding: A case study. Pages 151-160 in Proc. Annu. Meet. Natl. Mastitis Counc., Tampa, FL. National Mastitis Council, New Prague, MN.

Harner, J., M. Brouk, and J. Smith. 2009. Sand bedding and sand recovery. Page 126 in Proc. Four-State Dairy Nutrition and Management Conference. Madison, WI.

Hogan, J., K. Smith, K. Hoblet, D. Todhunter, P. Schoenberger, W. Hueston, D. Pritchard, G. Bowman, L. E. Heider, and B. Brockett. 1989. Bacterial counts in bedding materials used on nine commercial dairies. J. Dairy Sci. 72:250-258.

Hogan, J., and K. L. Smith. 2003. Coliform mastitis. Vet. Res. 34:507519.

Hogan, J. S., V. L. Bogacz, L. M. Thompson, S. Romig, P. S. Schoenberger, W. P. Weiss, and K. L. Smith. 1999a. Bacterial counts associated with sawdust and recycled manure bedding treated with commercial conditioners. J. Dairy Sci. 82:1690-1695.

Hogan, J. S., R. N. Gonzalez, R. J. Harmon, S. C. Nickerson, S. P. Oliver, J. W. Pankey, K. L. Smith, and National Mastitis Council. 1999b. Laboratory Handbook on Bovine Mastitis. National Mastitis Council, Madison, WI.

Ito, K., D. M. Weary, and M. A. G. von Keyserlingk. 2009. Lying behavior: Assessing within- and between-herd variation in free-stallhoused dairy cows. J. Dairy Sci. 92:4412-4420.

Jensen, M. B., L. J. Pedersen, and L. Munksgaard. 2005. The effect of reward duration on demand functions for rest in dairy heifers and lying requirements as measured by demand functions. Appl. Anim. Behav. Sci. 90:207-217.

Justice-Allen, A., J. Trujillo, R. Corbett, R. Harding, G. Goodell, and D. Wilson. 2010. Survival and replication of Mycoplasma species in recycled bedding sand and association with mastitis on dairy farms in Utah. J. Dairy Sci. 93:192-202.

Kristula, M. A., W. Rogers, J. S. Hogan, and M. Sabo. 2005. Comparison of bacteria populations in clean and recycled sand used for bedding in dairy facilities. J. Dairy Sci. 88:4317-4325.

Kurweil, R., and M. Busse. 1973. Total count and microflora of freshly drawn milk. Milchwissenschaft 28:427.
Lombard, J. E., C. B. Tucker, M. A. G. von Keyserlingk, C. A. Kopral, and D. M. Weary. 2010. Associations between cow hygiene, hock injuries, and free stall usage on US dairy farms. J. Dairy Sci. 93:4668-4676.

MacKay, J. R., J. M. Deag, and M. J. Haskell. 2012. Establishing the extent of behavioural reactions in dairy cattle to a leg mounted activity monitor. Appl. Anim. Behav. Sci. 139:35-41.

Manninen, E., A. M. de Passillé, J. Rushen, M. Norring, and H. Saloniemi. 2002. Preferences of dairy cows kept in unheated buildings for different kind of cubicle flooring. Appl. Anim. Behav. Sci. 75:281-292.

Norring, M., E. Manninen, A. De Passillé, J. Rushen, L. Munksgaard, and H. Saloniemi. 2008. Effects of sand and straw bedding on the lying behavior, cleanliness, and hoof and hock injuries of dairy cows. J. Dairy Sci. 91:570-576.

Ortiz, X., J. Smith, F. Rojano, C. Choi, J. Bruer, T. Steele, N. Schuring, J. Allen, and R. J. Collier. 2015. Evaluation of conductive cooling of lactating dairy cows under controlled environmental conditions. J. Dairy Sci. 98:1759-1771.

Reich, L. J., D. Weary, D. Veira, and M. Von Keyserlingk. 2010. Effects of sawdust bedding dry matter on lying behavior of dairy cows: A dose-dependent response. J. Dairy Sci. 93:1561-1565.

Schreiner, D., and P. Ruegg. 2003. Relationship between udder and leg hygiene scores and subclinical mastitis. J. Dairy Sci. 86:3460-3465.

Schukken, Y., J. Smit, F. Grommers, D. Vandegeer, and A. Brand 1989. Effect of freezing on bacteriologic culturing of mastitis milk samples. J. Dairy Sci. 72:1900-1906.

Tucker, C., D. Weary, and D. Fraser. 2003. Effects of three types of free-stall surfaces on preferences and stall usage by dairy cows. J. Dairy Sci. 86:521-529.

Van Gastelen, S., B. Westerlaan, D. Houwers, and F. van Eerdenburg. 2011. A study on cow comfort and risk for lameness and mastitis in relation to different types of bedding materials. J. Dairy Sci. 94:4878-4888.

Wagner-Storch, A. M., R. W. Palmer, and D. W. Kammel. 2003. Factors affecting stall use for different freestall bases. J. Dairy Sci. $86: 2253-2266$.

Zdanowicz, M., J. Shelford, C. Tucker, D. Weary, and M. Von Keyserlingk. 2004. Bacterial populations on teat ends of dairy cows housed in free stalls and bedded with either sand or sawdust. J. Dairy Sci. 87:1694-1701. 